-high-performance technologies at the US analysts International Data Corporation (IDC). The hard fact about making MPP supercomputers, he says, is that the market is small, stagnant and overcrowded; and the end of the cold war means that it is suffering from cuts in US defence research.

IDC estimates the size of the MPP supercomputer market to be $\$ 300$ million a year, and the entire supercomputer market to be $\$ 2.3$ billion, both relatively small figures compared to a total computer market of around $\$ 200$ billion. Commercial MPP systems, mostly large servers, are worth another \$300 million annually, and have higher growth potential than research or industrial supercomputers.

Thinking Machines is taking Willard's advice. It is expected to sell its hardware technology to Sun Microsystems, and use the cash to expand development of MPP software. "We were great at doing $R \& D$, but we were just no good at running a business," admits a company spokesperson.

The big question facing Europe, says Elliot, is whether it needs its own supercomputer industry at all. "It is difficult to make an economic case," he admits. Some say Europe would do better to concentrate on using other people's supercomputers to exploit the potential of such machines for improving industrial processes. But others argue that a home industry is needed precisely to provide the expertise to do this and point to CERN's new machine as evidence of its capacity to do so.

Declan Butler

\title{
Engine failure dents outlook for Japan's space industry
}

Tokyo. Japan's space programme suffered a major setback last week when the first large satellite to be launched by the country's new $\mathrm{H}-\mathrm{II}$ rocket was unable to propel itself into geostationary orbit because of a faulty apogee engine.

The 2-tonne satellite Kiku (Chrysanthemum) No. 6 cost nearly $¥ 70$ billion (US\$700 million) to build and place in orbit, a figure that includes $¥ 19$ billion for the launch alone.

But Kiku is now drifting in an elliptical orbit, unable to carry out most of the advanced communications experiments planned over a 10-year period. Its failure has dealt a serious blow to Japan's aspirations to enter the market for the commercial manufacture and launch of satellites.

At a press conference held in Tokyo last Thursday, Makiko Tanaka, the director general of the Science and Technology Agency (STA), which is responsible for the space programme, apologized for the failure, particularly given the amount of taxpayers' money involved. But she said progress was impossible without some waste: "I still believe the science is trustworthy," said Tanaka.

Kiku's difficulties stemmed from the failure of a valve in its Japanese-made liquid-fuel engine to open properly, despite several attempts. The valve eventually

\section{TI loses patent battle to Fujitsu}

Tokyo. The US semiconductor manufacturer Texas Instruments has lost the first round of a court battle against Fujitsu of Japan, which had challenged the US company's claim to a fundamental patent for integrated circuits on the grounds that the patent applies to old technology that is no longer in use.

But Texas Instruments points out that it took 29 years to win recognition from the Japanese Patent Office for its 'Kilby patent', which describes the first primitive integrated circuit invented by Jack Kilby in 1957.

The patent was finally granted in Japan in 1989, long after it had expired elsewhere in the world. The US company has since been earning millions of dollars in licence fees from Japanese electronics companies for the patent, which, because of the delays in its acceptance, will not expire until 2001. But Fujitsu balked at entering into a licensing agreement, and chose to fight Texas Instruments in the courts (see Nature 353, 488; 1991).

Last week, the Tokyo district court ruled in Fujitsu's favour. It concluded that two Fujitsu products, a 1-megabit dynamic random access memory and a 32-kilobit programmable read-only memory, do not infringe Texas Instrument's patent. The court also rejected a separate lawsuit by the US company intended to stop the use, production and sale by Fujitsu of these products.

Texas Instruments immediately announced it will appeal against the court's decision. "We are deeply disturbed by a patent system that keeps a major invention tied up in the Japan Patent Office for 29 years, and, when the patent is issued, in effect claims that it covers old technology and does not pertain to products made today," says Richard Agnich, senior vicepresident of the US company.

Agnich points out that the company was initially rebuffed in the Japan Patent Office, but persevered and eventually prevailed.

The US company's licensing agreements with several other Japanese companies will come up for renewal within the next two years and the court decision may well tempt these companies to resist entering new licence agreements for the Kilby patent.

D. S. jammed partially open, but as a result the engine was only able to achieve about 10 per cent of its required power, and the hefty satellite could not be boosted into geostationary orbit.

The last such mishap occurred in 1980 , when a US-made apogee engine on the experimental communications satellite Ayame No. 2 misfired and communication was lost. Ironically, it was partly because of that experience that the National Space Development Agency (NASDA) and Japanese industry joined forces to embark on a strategy for breaking free of dependency on US rocket technology, and to develop the technology needed to launch large satellites domestically, regardless of the cost.

The high costs of such Japanese-made technology - H-II launches, for example, cost nearly twice as much as equivalent launches in the United States, Europe and China - means that NASDA and industry have been stressing the reliability of their technology. But this particular H-II mission has been plagued with a series of technical failures. Indeed, it was only after three attempts that the rocket got Kiku off the ground (see Nature 371, 3; 1994).

Kiku's problems have drawn attention to the very high costs of NASDA's space programme. Tanaka, known for her outspoken views, reportedly told the Cabinet on the day after the press conference that "they [NASDA] make huge efforts to get their budget granted, but don't try so hard to use it effectively".

The Science and Technology Agency has requested a large 8.7 per cent increase of $¥ 183.7$ billion in the space budget for the next fiscal year (see Nature 371, 3; 1994). Kiku's failure may well adversely affect negotiations with the Ministry of Finance.

NASDA is still planning to attempt some experiments in the satellite's present elliptical orbit. But most of the planned experiments depend on it being placed in geostationary orbit.

One key set of experiments would have involved sending signals from a ground station via Kiku to other satellites in lower Earth orbit. That is now likely to be impossible, given that Kiku will be in constant motion over the Earth.

Despite the failure, NASDA says that future $\mathrm{H}-\mathrm{II}$ launches will proceed as planned, including the launch of an advanced communications satellite COMETS in fiscal year 1996, which will have a liquid-fuel apogee similar to the one that failed on Kiku. But agency officials do not anticipate any difficulties with this launch, as the structure of the fuel valve to be used is different.

David Swinbanks 